pharmacological effect if comparison is made with physiological concentrations of these oestrogens in the menstrual cycle. On the other hand, during pregnancy peripheral concentrations of oestrone and oestrone sulphate become much greater $^{19}$ than those measured in these postmenopausal women receiving oestrogens. Since the risk of endometrial carcinoma is greater in nulliparous than in multiparous women one might argue that raising oestrogen concentrations above those found during the menstrual cycle might even be protective against endometrial cancer; this is not borne out, however, by epidemiological evidence, ${ }^{1}{ }^{2}{ }^{2}$ ? and controversy continues.

The retrospective studies from the United States suggesting a link between hormone treatment at the menopause and endometrial carcinoma were concerned almost exclusively with unopposed oestrogen treatment, and one may speculate from our results that high concentrations of oestrone or oestrone sulphate rather than oestradiol are responsible. It seems unlikely to be harmful to maintain after the menopause oestradiol concentrations similar to those found during menstruation. Alternatively, since the major oestrogen used in the studies from the United States was a preparation of equine origin containing 20 different steroids, ${ }^{20}$ oestrone sulphate of human origin cannot necessarily be incriminated. A recent paper suggests that the excess risk of endometrial carcinoma applies to systemic oestrogens of various kinds, and not only to conjugated equine oestrogens. ${ }^{7}$ Good prospective epidemiological studies are needed to confirm or refute the American evidence but our results suggest that ingesting oestrone sulphate is unlikely to be associated with any greater risks of endometrial carcinoma than ingesting oestradiol.

We thank all patients who co-operated in this study, Abbott Laboratories for financial support, and Miss P Shepheard for typing the manuscript. The oestradiol antibody was the generous gift of Dr W Collins, King's College Hospital Medical School, London. The oestrone antiserum oestrone-6-carboxymethyloxime was obtained from Steranti Research Ltd, St Albans.

\section{References}

1 Smith, D C, et al, New England fournal of Medicine, 1975, 293, 1164.

2 Zeil, H K, and Finkle, W D, New England fournal of Medicine, 1975, 293, 1167.

${ }^{3}$ Cooke, I D, British Medical fournal, 1976, 1, 1209.

4 Studd, J, British Medical fournal, 1976, 1, 1144.

5 Lancet, 1977, 1, 577.

- Mack, T M, et al, New England fournal of Medicine, 1976, 294, 1262.

' Gray, L A, Christopherson, W M, and Hoover, R N, Obstetrics and Gynecology, 1977, 49, 385.

8 Siiteri, P K, Schwartz, B E, and MacDonald, P C, Gynecologic Oncology, $1974,2,228$.

- British Medical fournal, 1976, 1, 791.

10 Yen, S S C, et al, Fournal of Clinical Endocrinology and Metabolism, 1975, $40,518$.

11 Jacobs, H S, et al, Current Medical Research and Opinion, 1977, 4, suppl No 3, p 58.

12 Hawkins, R A, and Oakey, R W, Fournal of Endocrinology, 1974, 60, 3.

13 Reeder, H J, Loriaux, L, and Lipsett, M B, fournal of Clinical Investigation, 1972, 51, 1020.

${ }^{14}$ Longcope, C, fournal of Clinical Endocrinology and Metabolism, 1972, 34, 113.

15 Turnbull, A C, et al, Lancet, 1974, 1, 101.

${ }_{16}$ Ryan, K J, and Engel, L L, Endocrinology, 1953, 52, 287.

17 Diczfalusy, E, et al, Acta Endocrinologica, 1962, 40, 537.

18 Emment, Y, Collins, W P, and Sommerville, I F, Acta Endocrinologica, 1972, 69, 567.

19 Turnbull, A C, et al, in The Fetus and Birth, ed J Knight and M O'Connor, p 427. Amsterdam, Elsevier, 1977.

${ }^{20}$ Lauritzen, C, Frontiers in Hormone Research, 1975, 3, 30.

(Accepted 27 October 1977)

\title{
Serum tolbutamide and chlorpropamide concentrations in patients with diabetes mellitus
}

\author{
A MELANDER, G SARTOR, E WÅHLIN, B SCHERSTÉN, P-O BITZÉN
}

British Medical fournal, 1978, 1, 142-144

\section{Summary and conclusions}

A selective and sensitive gas chromatographic technique was used to measure the steady-state serum concentrations of tolbutamide and chlorpropamide in 97 patients with maturity-onset diabetes mellitus who had been taking these drugs (37 tolbutamide, 60 chlorpropamide) for at least a year. No other antidiabetic agents had been given. The serum tolbutamide concentrations varied widely between the patients (from close to zero to 370 $\mu \mathrm{mol} / 1(100 \mu \mathrm{g} / \mathrm{ml}))$, yet the variation in dosage was only sixfold (0.5-3.9 g daily). The serum chlorpropamide concentrations varied even more widely (from close to zero to $882 \mu \mathrm{mol} / 1(244 \mu \mathrm{g} / \mathrm{ml}))$, though the dosage variation was fourfold (125-500 $\mathrm{mg}$ daily). There was no

Lund University Hospital, EA-blocket 5tr, S-221 85 Lund, Sweden A MELANDER, MD, acting professor of clinical pharmacology G SARTOR, MD, resident, department of internal medicine E WÁHLIN, BSC, chemist, department of clinical pharmacology B SCHERSTÉN, MD, associate professor of internal medicine

Department of Community Care Sciences, Primary Care Centre, Dalby, Sweden

P-O BITZÉN, MD, district doctor systematic relation between dosage and serum concentrations of the drugs.

Only $2(5.4 \%)$ of the tolbutamide-treated patients and $10(16.7 \%)$ of the chlorpropamide-treated patients had normal fasting blood glucose concentrations (below $5.5 \mathrm{mmol} / 1$ (99 $\mathrm{mg} / 100 \mathrm{ml}))$, and fewer than half had values below $8.0 \mathrm{mmol} / 1$ (144 $\mathrm{mg} / 100 \mathrm{ml})$. In most cases, therefore, the treatment was insufficient.

There was no significant difference in mean fasting blood glucose concentrations between the two treatment groups. The mean steady-state concentration of chlorpropamide, however, was significantly higher than that of tolbutamide. Thus, contrary to common belief, the intrinsic activity of chlorpropamide is apparently not greater than that of tolbutamide. The alleged greater potency of chlorpropamide seems to be related wholly to kinetic differences, such as the less extensive metabolic degradation and slower elimination of the drug.

We conclude that treatment with sulphonylureas in conventional dosage is far from optimal and that monitoring the concentrations of these drugs in the blood may help to improve their efficacy.

\section{Introduction}

The choice of drug is a major prerequisite for successful treatment, but so also is adequate dosage. Much if not most of the 
variation in clinical response to a drug can often be related to interindividual differences in its metabolism. The steady-state blood concentrations of phenytoin, nortriptyline, and betaadrenergic antagonists, for example, may vary widely in patients given standardised doses. ${ }^{1-3}$ Maximum benefit from treatment therefore depends on optimum dosage in each case, and in this respect useful guidelines may be obtained by measuring drug concentrations in the blood. Recently oral antidiabetic agents such as tolbutamide and chlorpropamide were claimed to be virtually useless in the long-term management of diabetes mellitus, ${ }^{+5}$ yet no major clinical pharmacokinetic study has been carried out to enable the optimum dosage of sulphonylureas to be determined. Furthermore, such studies as have been conducted have used techniques that are neither sensitive nor selective enough for accurate determinations of steady-state concentrations of drugs in the blood. We have therefore used a selective and sensitive gas chromatographic technique to measure the steady-state serum concentrations of tolbutamide and chlorpropamide in diabetic patients given conventional doses of these drugs for at least a year. We also measured the fasting blood glucose concentrations. The results suggest that monitoring sulphonylurea concentrations in the blood may be of value in treating diabetes mellitus.

\section{Patients and methods}

We studied 97 patients with maturity-onset diabetes mellitus. They were aged $27-82$ years, weighed $45-90 \mathrm{~kg}$, and were regular attenders at the medical clinic, Lund University Hospital, or the community care centre, Dalby. All had conventional dietary restrictions and had been receiving tolbutamide (37 patients) or chlorpropamide (60 patients) for one to four years. (The doses are listed under Results.) So as not to prejudice their attitudes to treatment or cause them to change their eating habits the patients were not informed about the study.

Fasting blood samples were taken at about 8 am when the patients came for regular check-ups. They were asked only to abstain from their morning dose of the drug on the day of the visit. None of the patients were taking any other antidiabetic agents, though some were using drugs that may influence blood glucose concentrations, such as thiazides. Blood samples were taken by venepuncture. A portion was used for blood glucose determination, ${ }^{6}$ and serum was extracted from the remainder and kept at $-20^{\circ} \mathrm{C}$ until assayed. A selective and sensitive gas chromatographic technique was used. ${ }^{7}$ In brief, the drugs were extracted into toluene, back-extracted into alkali, and methylated with dimethyl sulphate. The methylated derivatives were extracted into $\mathrm{N}$-hexane, concentrated by evaporation, and chromatographed on a $3.8 \%$ SE-52 column in a Varian 1400 gas chromatograph, nitrogen being used as carrier. The possibility of chromatographic pyrolysis of sulphonylurea ${ }^{8}$ was obviated by using an all-glass system and a low injector temperature. Intra-assay variability was $1.1 \%$ (SD of a serum pool mean value). Mean values are expressed \pm their standard errors.

\section{Results}

Of the 37 patients taking tolbutamide, 23 were following a thricedaily regimen, 10 a twice-daily regimen, and 4 a once-daily regimen. Twenty-two patients were taking $1.5 \mathrm{~g}$ daily and eight $1.0 \mathrm{~g}$, three $0.5 \mathrm{~g}$, one $0.75 \mathrm{~g}$, one $2.0 \mathrm{~g}$, one $2.5 \mathrm{~g}$, and one $3.0 \mathrm{~g}$ daily (fig 1 ). Thus there was a sixfold variation in daily dosage, the mean dose being $1.4 \mathrm{~g}$ daily. There was no significant correlation between dosage and body weight $(r=0.07 ; P>0.05)$.

The steady-state serum concentrations of tolbutamide varied widely between the patients (fig 1), from close to zero to about $370 \mu \mathrm{mol} / 1$ $(100 \mu \mathrm{g} / \mathrm{ml})$. There was no systematic relation between dosage and serum concentration. The mean concentration was $104 \pm 15 \mu \mathrm{mol} / \mathrm{l}$ $(28 \pm 4 \mu \mathrm{g} / \mathrm{ml})$

All 60 patients receiving chlorpropamide were taking the drug once daily. Of these patients, 27 took a daily dose of $250 \mathrm{mg}$, while the others took $375 \mathrm{mg}$ (22 patients), $125 \mathrm{mg}$ (6), and $500 \mathrm{mg}$ (5) (fig 2). Thus there was a fourfold variation in dosage, the average daily dose being $304 \mathrm{mg}$. Again there was no significant correlation between dosage and body weight $(r=0.23 ; P>0.05)$.

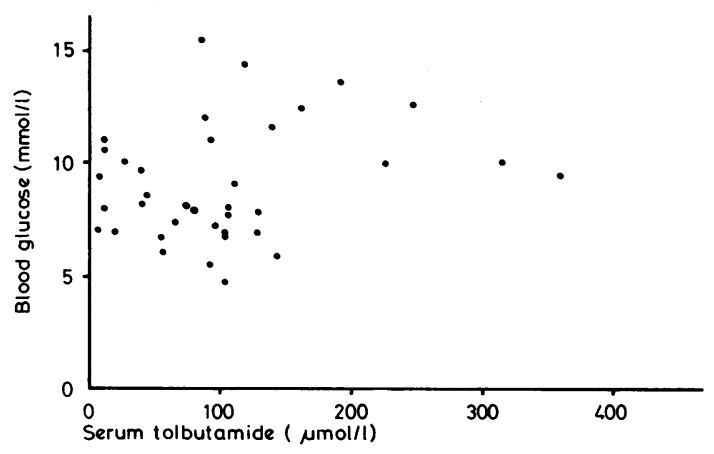

FIG 3-Serum tolbutamide and fasting blood glucose concentrations in the 37 patients receiving this drug. Conversion: $S I$ to traditional units-Blood glucose: $1 \mathrm{mmol} / 1 \approx 18 \mathrm{mg}$ / $100 \mathrm{ml}$. Serum tolbutamide: $1 \mu \mathrm{mol} / 1 \approx 0 \cdot 27 \mu \mathrm{g} / \mathrm{ml}$.

The steady-state serum concentrations of chlorpropamide showed a wider variation between patients than did those of tolbutamide, ranging from close to zero to $882 \mu \mathrm{mol} / 1(244 \mu \mathrm{g} / \mathrm{ml})$, with a mean of $262 \pm 24 \mu \mathrm{mol} / 1(72 \pm 7 \mu \mathrm{g} / \mathrm{ml})$. This mean value was significantly larger than that for tolbutamide $(P<0.001)$.

In the tolbutamide-treated patients the fasting blood glucose concentrations varied from 4.8 to $15.5 \mathrm{mmol} / 1(86.5$ to $279.0 \mathrm{mg} / 100 \mathrm{ml})$, with a mean of $9 \cdot 1 \pm 0.4 \mathrm{mmol} / 1(164.0 \pm 7 \cdot 2 \mathrm{mg} / 100 \mathrm{ml})$. In the chlorpropamide-treated group the range and mean values were 3.3$17.1 \mathrm{mmol} / 1(59 \cdot 5-308.0 \mathrm{mg} / 100 \mathrm{ml})$ and $8 \cdot 1 \pm 0.4 \mathrm{mmol} / 1(146.0 \pm$ $7.2 \mathrm{mg} / 100 \mathrm{ml})$ respectively. The mean values did not differ significantly between the two groups.
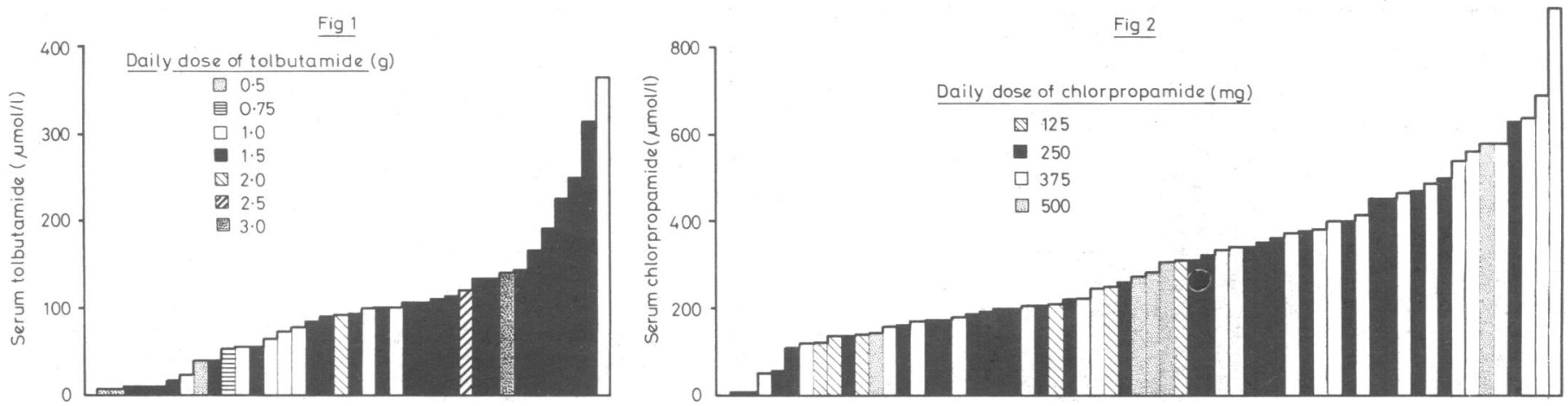

FIG 1-Steady-state concentrations of serum tolbutamide in 37 patients with diabetes mellitus treated with this drug for at least a year. Conversion: $S I$ to traditional units-Serum tolbutamide: $1 \mu \mathrm{mol} / 1 \approx 0 \cdot 27 \mu \mathrm{g} / \mathrm{ml}$. FIG $2-$ Steady-state concentrations of serum chlorpropamide in 60 patients with diabetes mellitus treated with this drug for at least a year. Conversion: SI to traditional units-Serum chlorpropamide: $1 \mu \mathrm{mol} / \mathrm{l} \approx 0 \cdot 28 \mu \mathrm{g} / \mathrm{ml}$. 
There were no apparent correlations between the steady-state serum concentrations of the drugs and the fasting blood glucose concentrations $(r=-0.25, P>0.05$ for tolbutamide; and $r=-0.071$, $\mathbf{P}>\mathbf{0 . 0 5}$ for chlorpropamide) (figs 3 and 4 ).

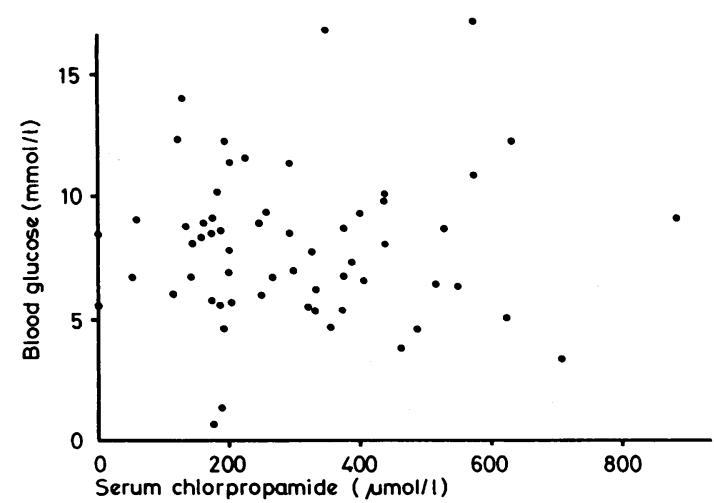

FIG 4-Serum chlorpropamide and fasting blood glucose concentrations in the 60 patients receiving this drug. Conversion: SI to traditional units-Blood glucose: $1 \mathrm{mmol} / 1$ $\approx 18 \mathrm{mg} / 100 \mathrm{ml}$. Serum chlorpropamide: $1 \mu \mathrm{mol} / 1 \approx 0.28$ $\mu \mathrm{g} / \mathrm{ml}$.

\section{Discussion}

A major finding in this study was the large interindividual difference in steady-state serum concentrations of the two drugs. Thus the serum concentrations of tolbutamide ranged from almost zero to $370 \mu \mathrm{mol} / \mathrm{l}(100 \mu \mathrm{g} / \mathrm{ml})$, whereas the dosage difference was only sixfold. For chlorpropamide the range of concentrations was even greater-from almost zero to 882 $\mu \mathrm{mol} / \mathrm{l}(244 \mu \mathrm{g} / \mathrm{ml})$ - though the dosage difference was only fourfold.

Large interindividual differences in serum concentrations have been observed for several other drugs-for example, phenytoin, nortriptyline, and beta-adrenoceptor antagonists. ${ }^{1-3}$ In these cases the major reason is the great interindividual variation in drug-metabolising capacity. ${ }^{1-3}$ This may be true also for tolbutamide, which is metabolised to a large extent. ${ }^{9}$ For chlorpropamide, differences in renal excretion may add to the variation, as this drug is only partially metabolised. ${ }^{10}$ Interindividual differences in drug bioavailability and compliance with treatment are probably additional causes of variation.

Another striking observation was that in most cases the treatment seemed to be insufficient. Indeed, only two patients in the tolbutamide group $(5 \%)$ and 10 in the chlorpropamide group $(16.7 \%)$ had entirely normal fasting blood glucose concentrations (below $5.5 \mathrm{mmol} / 1(99 \mathrm{mg} / 100 \mathrm{ml})$ ). Moreover, fewer than half in each group had fasting concentrations below $8 \mathrm{mmol} / 1(144 \mathrm{mg} / 100 \mathrm{ml})$. This finding agrees with previous observations and might support the view that sulphonylureas are almost useless in the long-term management of diabetes mellitus. ${ }^{45}$ The enormous variation in steady-state concentra- tions of the drugs, however, suggests another possibilitynamely, that the conventional dosage of sulphonylureas is far from optimal and that the dosage of tolbutamide and chlorpropamide should be carefully selected to suit individual cases.

A crucial question is whether there is an inverse relation between the steady-state concentrations of the sulphonylurea in the serum and the fasting concentrations of blood glucose. This cannot properly be examined unless dietary regimens and other factors known to influence blood glucose concentrations are standardised. We deliberately avoided such standardisation, however, because we wished to study the therapeutic effect of conventional routines.

The molecular weights of tolbutamide and chlorpropamide are closely similar (270.4 and 276.7 respectively) and their mechanisms of action are probably identical. ${ }^{11}$ Chlorpropamide is considered to be more potent than tolbutamide, however, and the most common daily dose of chlorpropamide is one-sixth that of tolbutamide. But when the mean steady-state concentrations of tolbutamide and chlorpropamide were compared, the chlorpropamide value was found to be almost three times larger than the tolbutamide value, whereas the mean blood glucose concentrations did not differ significantly. Hence contrary to common belief the intrinsic activity of chlorpropamide is apparently not higher than that of tolbutamide. The alleged greater potency of chlorpropamide seems to be related wholly to kinetic differences, such as the less extensive metabolic degradation and the slower elimination of the drug.

Irrespective of the possible differences between the two compounds, probably both drugs are often given in suboptimal dosage. Thus monitoring the sulphonylurea concentrations in blood may be of value in the management of diabetes mellitus. Studies are in progress to elucidate further the relations between dosage, mode of administration, blood concentrations, and effects of sulphonylureas on insulin release and glucose disposition.

\section{References}

${ }^{1}$ Lund, L, in Biological Effects of Drugs in Relation to their Plasma Concentrations, London, Macmillan Press, 1973.

2 Alexanderson, B, Åsberg, M, and Tuck, D, in Biological Effects of Drugs in Relation to their Plasma Concentrations. London, Macmillan Press, 1973.

3 Johnsson, G, and Regårdh, C G, Clinical Pharmacokinetics, 1976, 1, 233.

4 Shen, S-W, and Bressler, R, New England fournal of Medicine, 1977, 296, 493.

${ }^{5}$ Shen, S-W, and Bressler, R, New England fournal of Medicine, 1977, 296, 787.

${ }^{6}$ Coburn, H J, and Carrol, J J, Clinical Chemistry, 1973, 19, 127.

7 Prescott, L F, and Redman, D R, Fournal of Pharmacy and Pharmacology, $1972,24,713$

${ }^{8}$ Simmons, D L, Ranz, R J, and Picotte, P, fournal of Chromatography, $1972,71,421$.

${ }^{9}$ Hamwi, G J, Current Medical Digest, 1966, 33, 1184.

10 Taylor, J A, Clinical Pharmacology and Therapeutics, 1972, 13, 710

11 Larner, J, and Haynes, R C, jun, in The Pharmacologic Basis of Therapeutics, ed L S Goodman and A Gilman, p 1507. New York, Macmillan, 1975.

(Accepted 31 October 1977) 